\title{
Chinese economic reform and development: achievements, emerging challenges and unfinished tasks
}

\section{Jane Golley and Ligang Song}

The economic transformation that has taken place in China since the late 1970s is now regarded as one of the most significant social changes in human history. Within just three decades, China has succeeded in transforming itself from a centrally-planned closed economy into one of the world's most dynamic and globally-integrated market economies. The dynamics unleashed by Deng Xiaoping's reforms, open-door policies and institutional changes have unleashed enormous entrepreneurial energy and propelled continuous capital accumulation, productivity gains and trade and income growth on a scale the world has never seen before. During this period, China's total gross domestic product (GDP), industrial output, foreign trade and, importantly, its per capita income increased respectively by factors of 16, 27, 124 and $12 .^{1}$ As a result, the incidence and severity of poverty have declined dramatically in China. According to a recent World Bank report (2009), between 1981 and 2004, the fraction of China's population consuming less than US\$1 a day in today's purchasing power fell from 65 per cent to 10 per cent and about half a billion people were lifted out of poverty. This achievement has contributed critically to global progress in reducing world absolute poverty and indeed 'a fall in the number of poor of this magnitude over such as short period is without historical precedent' (World Bank 2009:iii). ${ }^{2}$

The fundamental causes of this remarkable performance are by now familiar to most China observers. Market-oriented reforms centred on changes in the price system led to improved resource allocation and allowed the most dynamic private sector to flourish, thereby increasing the overall level of efficiency in the economy. Liberalisation programs allowed trade and foreign direct investment

1 Calculated using the data taken from NBS (2009).

2 The Millennium Poverty Reduction Target aims to halve the proportion of people living in absolute poverty by 2015 compared with the level in 1990 (Thirlwall 2006). 
(FDI) to flourish according to China's underlying comparative advantage, resulting in enormous gains from trade. Decentralisation and ownership transformation helped to solve incentive problems and enhance the performance of firms and local governments. And institutional reforms that abandoned the decades-long restraints on the mobility of labour unleashed an unprecedented scale of urbanisation, with the ratio of the urban in the total population rising from less than 20 per cent in the late 1970s to 46 per cent in 2009. This gradual process of 'reform and opening up' coincided with a surge in the proportion of the working-age population, generating in a 'demographic dividend', which, according to Cai and Wang (2005), accounted for about one-quarter of the growth rate in per capita GDP between 1982 and 2000. The sustained high rates of economic growth that resulted have fundamentally transformed the Chinese economy and its position in the world.

China has also benefited during the past three decades from some favourable internal and external conditions. Internally, there were some positive legacies inherited from the planning system that were conducive to reform and growth, including a basic industrial base and reasonable infrastructure, the irrigation system and a relatively well-developed education system. In the aftermath of the Cultural Revolution, there were overwhelming domestic forces pushing for reform that helped overcome the resistance to change, especially during the early years of reform. The low base from which the economy started enabled China to benefit from low-cost advantages in production that contributed enormously to the rising output and competitiveness of the economy. Moreover, as a latecomer to economic development, China enjoyed the advantage of backwardnessthat is, the ability to adopt the world's more-advanced technologies relatively rapidly.

Externally, China's reforms have coincided with a new era of globalisation, characterised by a more open global trading environment, resulting from significant reductions in tariffs and other forms of trade protection through various rounds of multinational trade negotiations in the post-war period, and from the mid-1980s through unilateral liberalisation in the Western Pacific region. This era has also been characterised by rapid global economic structural adjustment in response to cross-border flows of capital, people and technology; and by rapid reductions in transaction costs stemming from substantial improvements in transport, communication and information management. 'As a result, international markets have provided China with opportunities (and also risks) that far exceed those available at the time of Japan's and Korea's big growth spurts' (Brandt and Rawski 2008:13).

While some of these favourable conditions will remain in place during the next two decades, many of them will no longer yield the sizeable benefits to China's economic growth that they have in the past. If China is to continue along its 
remarkable path of economic reform and development, it will need to adapt to these changing internal and external conditions and to steer skilfully through a number of challenges. This book highlights how the deepening of reforms in critical areas such as domestic factor markets, the exchange rate regime and the health system, combined with the strengthening of channels for effective policy implementation and the rebalancing of economic growth, will enable China to cope with the challenges that lie ahead. These include responding to the pending exhaustion of the unlimited supply of labour; playing a constructive role in reducing global trade imbalances; enhancing firms' ability to innovate and compete in the global economy; coping with migration, urbanisation and rising inequalities on scales unknown in world history; and dealing with rising energy and metal demand in an era in which low-carbon growth has become a necessity rather than a choice.

Evidence presented in this volume and elsewhere indicates that China has entered the turning point - or more accurately, the turning period - in economic development, signalled by the end of surplus labour and the consequent rapid rise in wages in some, albeit not all, sectors of the economy. The tightening of the labour market will be compounded by the combined impact of three decades of the One-Child Policy and rapid income growth on Chinese fertility rates, which has already heralded a rapidly ageing population, with the growth rate of the labour supply predicted to turn negative by about 2020 (Tyers et al. 2009). This will necessitate changes in the industrial structure and composition of trade, as China loses its comparative advantage in the labour-intensive exports that have been an engine of growth in the past. To facilitate these changes, building human capital through education, accelerating technological change through innovation and raising labour productivity through further labour-market reform are becoming increasingly urgent national priorities.

Economic growth in the past has been characterised by extensive growth resulting in a number of structural imbalances, including highly resourceand energy-intensive production. Now China has entered a stage of growth in which metal and energy intensities (that is, consumption per unit of GDP) are exceptionally strong. This will significantly add to the global pressure to balance the supply of, and demand for, resources and energy products, and the impact on world markets for these products is likely to be intense (Garnaut and Song 2006). Confronting this challenge will require China to accelerate its pace of structural change by moving more quickly towards higher valuedadded industrial production and the service sector and by adopting resourceand energy-saving technologies in all productive sectors. Reforming the pricing systems for energy and resources so that prices truly reflect the balance 
between supply and demand will be critical in this regard. Such pricing reforms will enhance supply capacities and encourage resource- and energy-saving technological change, substitutions for resource use and conservation.

As one of the largest economies and the largest carbon emitter in the world, China needs to confront environmental degradation and climate change by moving more rapidly towards a low-carbon growth economy. This is not only for the health and welfare of China's own population, but for the world to stand any chance of achieving the goal of significantly reducing global emissions before catastrophic problems occur (Stern 2007; Garnaut 2008). In so doing, China will need to overcome many difficulties associated with the current level of per capita income, the mid-phase of its industrialisation and the vast regional disparities with respect to the levels of income and industrial development. The transition towards developing a low-carbon economy might not necessarily compromise economic growth, as developing environmentallyfriendly industries can generate new sources of growth. The key challenge is to set up an appropriate system in which all parties involved, including the central government, local governments, firms and households, will have incentives to make the necessary adjustments (Cai and Du 2008). The stark conflict between the contemporary style of industrial development and the health of the biosphere indicates strongly that now is the time for China to make the adjustments that will underpin sustainable long-term growth (McKay and Song 2010).

Enhancing productivity is a crucial component of the shift towards a low-carbon mode of economic growth. Technological progress and innovation hold the key. There is huge potential for China to change the relationship between economic output and carbon emissions through the absorption, mass production and improvement of green technologies from the developed countries. Government will play a crucial role in ensuring that China reaches this potential, most importantly by facilitating the dynamic private sector's active engagement in this endeavour. A concerted effort to generate and commercialise environmentallysound technologies would also enable China to quicken the pace of industrial structural change and alter the current trajectory of its industrialisation path.

Another feature of China's growth strategy has been the reliance on exports and investment, which has contributed to the rise in global imbalances in recent decades and to numerous structural problems within China as well. While not all of the remedies lie in China's hands, there is now widespread recognition that a rebalancing of growth is called for, in the direction of a strategy that relies more heavily on the growth of domestic consumption and productivity. Boosting domestic consumption will take time but there are some clear reform options that will play a positive role. Song et al. (forthcoming), for example, show that an effective way of boosting domestic demand is to accelerate the pace of 'urbanising' migrant workers (estimated to have reached 160 million 
in China in 2009) by granting these workers urban residency, which would change their consumption behaviour. This particular task can be accomplished only by deepening institutional reforms affecting labour mobility and the social security system. Ongoing economic development will also play a role. As China enters the turning period, higher wages will naturally lead to higher domestic consumption, possibly having a greater impact than any institutional reforms. Higher consumption will raise China's import demand, enabling the country to contribute to more balanced growth in the global economy and to become a sustainable engine for global growth. Reforms to China's exchangerate regime and land-management system will also play crucial roles in solving a range of imbalance issues. Low domestic consumption is just one of many indicators that China's growth strategy needs to be readjusted as far as its social impact is concerned. For example, the World Bank (2009) has found that the responsiveness of poverty reduction to economic growth has fallen in recent years. Rising income inequality and widening regional disparities, along with uneven access to health services and social welfare systems, are some of the most undesirable outcomes associated with the rapid economic growth of the past. Failure to deal with these issues could pose the greatest threats to social stability, which in turn could become a serious obstacle for growth and development in the decades ahead. While entering the turning period will offer some respite for income inequality, much more will need to be done. Apart from strengthening the redistributive functions of the government and building a more comprehensive social security system, further reforms to enhance ruralurban migration will be crucial for the continued growth of productivity and income while narrowing the income inequality among different social groups. Strengthening local public finance through reforming the current system of intergovernmental transfer payments and improving the health system will also be critical if the government is to achieve its objective of more equitable development.

Finally, China is likely to become the largest economy in the world by 2030, regardless of the measurement used (Maddison 2001). China's rise as a global economic powerhouse will thrust on it increasing responsibilities in a range of global affairs - whether it wants those responsibilities or not. China will thus be expected, and will surely find it desirable, to contribute positively to global stability, progress and prosperity through cooperation with other players in the global system. High on the agenda for China's strategic engagement are reducing global imbalances, reforming the international financial system, pushing forward with multilateral trade negotiations under the World Trade Organisation (WTO), confronting the challenges of climate change and fighting global poverty. In all of these realms, it is not merely a question of how China manages its external economic relations but how it conducts itself politically. 
China has made tremendous progress in reforming its institutions in the first 30 years of reform and transformation. What has been achieved in the past has laid the groundwork for China to deepen institutional reforms during the next stage of its development. There is reason to be optimistic as far as the link between future institutional change and growth is concerned, since '[o]nce economic growth has begun, institutions change more and more in directions favourable to growth, and so strengthen the forces making for growth' (Lewis 1955:143). China's experience during the past 30 years illustrates this point.

The next two decades of reform and development are likely to be more challenging than the past, as China embraces a new mode of economic growth driven not only by efficiency, but also sustainability and equity considerations. Indeed, the overarching challenge for China in the decades ahead is to successfully shift into this new mode of growth. This will not be possible unless China tackles the overarching task that remains unfinished: completing the transition to a true market economy by further reforming the country's factors markets and carrying out more comprehensive institutional reforms - in the economic system, in governance, in its legal and regulatory systems, as well as in the political system. If successful, the next two decades will see China elevated to a position of global primacy or at least of 'co-primacy' alongside the United States. Success is, however, more easily presumed than achieved. A smooth Chinese ascendancy to global primacy will require many changes from the status quo, as each of the chapters that follow demonstrates from a variety of different angles.

Part I of this book focuses on China's long-term development trends and issues. It begins with Ross Garnaut's (Chapter 2) analysis of the turning period in Chinese development. Garnaut presents a new conceptual framework based on Arthur Lewis's model of economic development in a labour-surplus economy, which provides the basis for understanding China's transition through the end of this period of labour surplus and beyond. He reflects on chapters in the 2006 China Update book, The Turning Point in China's Economic Development, which provided early and partial evidence that China had already begun its entry into the turning period. This is followed by a summary of more recent evidence that the economy has now moved more decisively and deeply into this period, signalled in particular by rapidly rising real wages since 2004. Garnaut sees China's economic success in the future depending on the flexibility of the economy; its openness to foreign trade, investment and ideas; and the quality of human resources and regulatory systems that are required to deal with the more complex economy that is emerging. He argues that, with this flexibility and structural adjustment, the growth of the Chinese economy will not necessarily slow during the Lewis turning period and beyond.

China's gradual and piecemeal approach to economic reform has been heralded by many as an alternative - and preferable — path to economic development, as 
reflected in the discourse about the 'Beijing Consensus' versus the 'Washington Consensus'. Where the Beijing Consensus has often been interpreted as a development model in which an authoritarian government is heavily involved in most economic activities, the Washington Consensus has been interpreted as a development model requiring a relatively rapid transition to a market-based economy as prescribed by neoclassical economics. Yang Yao (Chapter 3) contests both of these interpretations in his analysis of China's development model and sees China's reform and development as being perfectly compatible with the Washington Consensus, and the 'China model' as a process of convergence towards neoclassical ideals. Yao describes the Chinese government as a 'disinterested' government that has managed to remain detached from various social groups within China rather than being captured by exclusive interest groups. This 'disinterest' - rather than its authoritarianism-has enabled growth-enhancing policies, which, while creating winners as well as losers, have collectively delivered higher living standards across the nation in the past three decades. Despite this success to date, Yao concludes that China's future development model will inevitably require explicit political reform, and ideally democratisation, to counterbalance the formation of strong interest groups with increasingly contradictory goals - beyond that of economic growth alone.

Where Yao argues for democratisation in the future as a way of balancing government actions and public interests, Yongsheng Zhang (Chapter 4) sees it as a way to establish effective central-local government relationships, the evolution of which will have a crucial impact on China's future development. He proposes a new analytical framework for intergovernmental relations based on two distinct dimensions - personnel and fiscal - each of which can be either 'top down' or 'bottom up'. This gives rise to four possible structures into which the world's wide range of intergovernmental relations can be categorised. Zhang argues that most industrialised Western countries fall into Structure 1, represented by the combination of bottom-up personnel relationships and top-down fiscal relationships. China's evolving central-local relations during the reform period are then depicted as a journey from Structure 3 (top-down personnel, topdown fiscal) to Structure 4 (top-down personnel, bottom-up fiscal), as a result of fiscal decentralisation between 1978 and 1994, and then back to Structure 3 after the 1994 tax reforms. Zhang suggests that the most likely outcome for China in the foreseeable future is that central-provincial relations continue to be top-down personnel and top-down fiscal (Structure 3), while provinciallocal relations become increasingly bottom-down personnel, top-down fiscal (Structure 1). For the successful evolution towards Structure 1 for all levels of intergovernmental relations in China, Zhang sees two critical requirements: the strengthening of the rule of law and the deepening of grassroots democracy 
over time. Like so much of China's reform and development process, however, Zhang is clear that this process will be gradual and certainly not without Chinese characteristics.

Huw McKay, Yu Sheng and Ligang Song (Chapter 5) revive the theoretical field that relates economic development to metal usage and shed light on China's future path of ferrous-metal demand by referencing the experience of relevant peers over the entire course of the industrialisation process. Their chapter formally identifies the existence of the Kuznets inverted-U curve for steel (KCS) and validates the synthesis view of metal intensity, which sees a role for both technological leapfrogging and evolving consumer preferences in determining changes in metal intensity. Their econometric analysis indicates that China will reach the turning point in its own KCS when its gross domestic product (GDP) per capita exceeds about US\$15 000 - predicted to be about 2024. They conclude that, as China progresses towards high-income status, it is unlikely to continue to closely follow the Korean path characterised by its exceptionally high metal intensity. This is because China will be compelled to alter its mode of economic growth away from the current reliance on heavy industry, investment and export orientation. As a consequence, China's final path of metal intensity is likely to be a blend of certain aspects of the experiences of North America, the Commonwealth of Independent States, Western Europe, Japan and emerging Asia.

The global and local environmental consequences of China's rapid growth and industrialisation during the past three decades have been immense. There is increasing pressure within and outside China for the Chinese leadership to be more ambitious in their plans to combat global climate change and, according to Zhongxiang Zhang (Chapter 6), they are at least beginning to step up to the plate. This is reflected first and foremost in China's target to reduce its carbon intensity by $40-45$ per cent by 2020 - a target that goes well beyond 'business as usual'. Zhang is well aware that stating ambitious targets is one thing, while achieving them is another. On this front, he recognises that the (lack of) reliability of China's energy and GDP statistics makes it difficult to assess real progress while raising the issue of credibility as well. Moreover, the conflicting objectives of lower-level governments could result in actions that counteract rather than support national-level environmental objectives. These issues notwithstanding, he provides considerable and detailed evidence of the achievements to date in terms of energy conservation and carbon-intensity reductions. Zhang concludes that the likelihood of China achieving its environmental goals rests on the strengthening of existing policies, industrial restructuring away from highly energy-consuming, polluting and resource-intensive industries and the cooperation of local governments. 
Jane Golley (Chapter 7) reflects on an issue that has plagued Chinese leaders for millennia: regional disparities in development. By 2050, the current leadership has set itself the formidable task of 'considerably reducing' the disparities that exist between western China and the other regions - most prominently, the east, where the vast share of China's industrialisation has occurred throughout time, and in particular, throughout the reform period. Golley's analysis of provincial-level industrial growth rates during the period 2000-07 provides some indication that the glory days of the eastern region could be coming to an end, although its dominance in terms of China's industrial output is still clearly evident. Although she finds some theoretical and empirical reasons for optimism on the likelihood that some industries will spread westward in the next two decades, the balance of evidence suggests this will translate into no more than a minimal reduction in regional disparities during this time. Reducing regional inequalities will remain unfinished business in China for a long time to come.

Part II of the book turns to the challenges and opportunities relating to China's global integration. Xiao Geng (Chapter 8), and Rod Tyers and Ying Zhang (Chapter 9) contribute to the continuing renminbi exchange-rate debate. Both chapters begin by reflecting on the international pressure for renminbi appreciation, which stems from the expectations of the Balassa-Samuelson hypothesis (BSH): a developing country experiencing productivity catchup in its tradable goods sectors is likely to experience a rising real exchange rate as a consequence of the associated rise in wages and non-tradable sector prices. Focusing on the problem of global imbalances, Xiao takes it as given that China will remain reluctant to appreciate the renminbi and considers alternative Chinese policy options - such as privatisation and deregulation - to reduce the excessive savings of the corporate sector and measures to increase domestic consumption. He then turns to what he sees as the key factor driving global imbalances: cheap money. This, he argues, has created property and stock-market bubbles all over the world, including in China, and has also had a significant impact on driving down the prices of Chinese goods (thereby keeping the real exchange rate low). Xiao calls for a higher Chinese interest rate and improved capital-control mechanisms to combat this, by ensuring that capital flows into efficient investments - whether domestic or international-rather than towards speculative and inefficient investments. He closes by noting that the rise in Chinese prices in the future can achieve the necessary real exchange rate appreciation, if and when China is able to tolerate this. The sooner this happens, the sooner external pressure for renminbi appreciation will subside.

Tyers and Zhang look closely at China's real exchange rate movements over time, observing that, despite the expectations of the $\mathrm{BSH}$, it showed no tendency to appreciate until after 2004. Since then, substantial real appreciation has taken place, which they attribute primarily to rising prices and wages in agriculture, 
along with the slowing of trade reforms. They then explain clearly why the setting of the renminbi rate is not as discretionary for the Chinese authorities as suggested by critics and that, should international pressure result in a nominal appreciation either via a monetary contraction or via export disincentives, the consequences would be harmful for Chinese and global interests. Both this chapter and Xiao's demonstrate the importance of understanding the peculiarities of China's transitional economy when entering into one of the world's hottest debates.

Chunlai Chen (Chapter 10) addresses the question of whether China's phenomenal success in attracting foreign direct investment (FDI) during recent decades has been at the expense of other developing economies - in Asia in particular. His econometric analysis of the 'China effect' on FDI into 12 other developing Asian economies during the period 1992-2008 suggests the commonly expressed fears about China's FDI dominance are unfounded. In particular, Chen finds that an increase in FDI inflows into China is positively and significantly related to FDI inflows into other Asian economies. He attributes this investment-creation effect during the period of analysis to the increased resource demand by a rapidly growing Chinese economy and the production-networking activities within Asia. Chen predicts that these positive linkages are likely to strengthen in the next two decades, in light of deepening Asian integration and expectations of continued rapid growth for China. Moreover, with the ageing and increasing wealth of China's population, not only will other Asian economies become more attractive alternative locations for labour-intensive manufacturing, they are likely to be the destinations of choice for China's increasingly large FDI outflows. For developing Asia, on average at least, China's FDI success is a win-win story.

Prema-chandra Athukorala and Archanun Kohpaiboon (Chapter 11) examine the export experience of China and other East Asian economies in the aftermath of the global financial crisis against the backdrop of pre-crisis trade patterns. The analysis is motivated by the 'decoupling' thesis, which posits that the East Asian region has become a self-contained economic entity with the potential for maintaining dynamism regardless of the economic outlook in the industrialised world. Athukorala and Kohpaiboon dispel this thesis by examining the changes in intra and extra-regional trade shares in East Asia since the global financial crisis. Emphasising the importance of including parts and components - as well as final goods - in trade-flow analysis, they show that the rising importance of global production sharing has in fact strengthened, rather than weakened, East Asia's links with the wider global economy. Noting that the global recovery is likely to remain patchy at best in the medium term, they call for an integrated East Asian policy response that emphasises rebalancing growth away from exports and towards domestic markets, particularly in the case of China. Their findings caution against a possible policy backlash against openness to foreign 
trade arising from the newly found enthusiasm for rebalancing growth and they make a strong case for a long-term commitment to non-discriminatory multilateral and unilateral trade liberalisation.

On the impact of the global financial crisis on rural-urban migration, Sherry Tao Kong, Xin Meng and Dandan Zhang (Chapter 12) reveal some unexpected findings. With the global financial crisis leading to a sharp reduction in export orders in the second half of 2008, it was expected that the most significant impacts would fall on rural migrants - in terms of either employment or wage reductions - and indeed millions of laid-off migrants lamented lost jobs and protested over closed factories. Drawing on the panel surveys of rural-urban migrants and rural households in the Rural-Urban Migration in China and Indonesia (RUMiCI) Project, Kong, Meng and Zhang find, however, only very small changes in employment and almost no wage reductions for migrants in cities between 2008 and 2009. Instead, they find that the real effects were felt mainly in the rural sector, to which close to 15 million rural migrants returned in 2009, and with 80 per cent of those taking up jobs in the rural agricultural sector. Thus, it was the agricultural sector that effectively provided an employment buffer for return migrants and also for workers in the rural off-farm sector, which was also hit by the economic downturn. Although this evidence indicates a relatively - and surprisingly - positive outcome for migrants during the global financial crisis, the authors point out that the agricultural sector is unlikely to provide such a buffer in the future, so migrant employment shocks will have to be absorbed in other ways. A universal welfare system and property rights over rural land are seen as crucial in this regard.

Section III of the book focuses on 'Policy and reforms: unfinished tasks'. It begins with Wing Thye Woo's depiction (Chapter 13) of the Chinese economy as a speeding car that is running the risk of three potential types of failure. Fiscal instability and a slowdown in productivity growth are discussed as two potential 'hardware' failures - or breakdowns in a key economic mechanism. Flaws in governance are likened to a crash caused by people fighting in the car - a potential 'software' failure - while severe environmental degradation is seen as a natural or externally imposed limit, a 'power supply' failure analogous to crashing into a wall. After explaining the reasons why each of these particular failures might occur in the foreseeable future, Woo presents a reform agenda to avert the occurrence of these, and other, potential obstacles along China's road to prosperity. His agenda for addressing hardware failures includes the creation of more new entrepreneurs, urbanisation according to the principle of future homeownership and the development of a modern financial system in which the private sector has a greatly enhanced role. Political reforms lie at the heart of his 'software reforms', which require the adoption of free elections, a free press and an independent judiciary. The solution to 'power supply' failures rests on 
China's ability to mobilise international consensus, cooperation and scientific research on key global issues. If adhered to, Woo's reform agenda offers much hope that China's rocky path to prosperity can be smoothed out significantly.

Yiping Huang and Bijun Wang (Chapter 14) examine the evolution of structural imbalances in China and offer one overarching solution: factor-market reform. In particular, they demonstrate that the fundamental cause of China's structural imbalances - reflected in its very high investment share of GDP and current account surplus, inefficient resource use, income inequalities and environmental degradation - lies in the gradual and piecemeal approach to economic reforms in which product markets have been completely liberalised while distortions in factor markets have remained. This has resulted in the repression of prices for labour, land, capital, resources and the environment, which Huang and Wang interpret as providing subsidy equivalents for producers, exporters and investors. While this has clearly been beneficial for China's economic growth in the past, it has also increased the structural risks associated with incomplete reforms, which will threaten the stability, balance and sustainability of China's growth pattern in the future unless adequately addressed. Huang and Wang note that the efforts of the Chinese leadership to date in addressing these issues have been limited and they call for a major shift in policy towards a comprehensive package of factor-market reforms. Only after the successful implementation of these reforms - which is likely to take decades in some areas - will China's transition to a market economy be truly complete.

Almost all aspects of China's economic reform and development process have exhibited uniquely 'Chinese characteristics' and Cai Fang and Meiyan Wang (Chapter 15) show that urbanisation is no exception. Their chapter begins with evidence that China has already reached the Lewis turning 'point', which they point out is in fact more a transitional 'period', beginning in 2004. Their investigation of recent trends in rural-to-urban migration and more general changes in the labour market shows that agriculture no longer serves as a pool of surplus labour, but rather that rural workers' migration to and settlement in urban areas have become irreversible and inevitable. As a consequence, one of their key arguments is that Chinese policymakers need to let go of the 'Todaro dogma', which depicts labour migration in a dual economy as a pattern of 'come and go', rather than of permanent settlement, and which thus results in the implementation of policies that control and even restrict the process of rural-to-urban migration - as exemplified by China's hukou system. While acknowledging progress in reforming the hukou system to date, Cai and Wang explain that impediments in the system have resulted in the transformation of farmers into migrant workers without entitlement to crucial public services and social protection in their urban destinations, thereby driving urbanisation 
with Chinese characteristics. Further hukou reforms are seen as critical for transforming these farmers-turned-migrant workers into migrants-turnedurban residents in the decades ahead.

For Yanrui Wu (Chapter 16), indigenous innovation will be crucial for sustainable growth and development in China in the decades ahead. After reviewing China's achievements in innovation, skills and capacity during the past three decades, $\mathrm{Wu}$ presents an econometric analysis of Chinese innovation at the firm level and then considers China's performance in an international context. After showing that rapid growth in investment in innovation has resulted in a rapid expansion of innovation outcomes, Wu then demonstrates a significant gap between China and the world's leading innovators and questions whether growth in the quantity of innovations has come at the expense of quality. While closing this gap and promoting quality are two obvious policy recommendations that stem from Wu's analysis, his firm-level analysis presents more of a policy dilemma. In particular, he shows that state-owned enterprises (SOEs) have performed much better than foreign-invested firms and privately owned Chinese firms as far as research and development propensity and efforts are concerned. Wu calls for specific policies to encourage the participation of non-state firms in innovation and to improve the legal system and protection of intellectual property in order to ensure that privatisation does not come at the expense of innovation in the future.

Finally, Ryan Manuel (Chapter 17) focuses on one particular aspect of China's reforms that is sparking much discontent - and with good reason: the healthcare system. Manuel provides some historical context for China's healthcare experience. After noting the achievements of the collective period (1950-79), in which China's public health system was world leading in terms of its high levels of 'bang for your buck', he describes the second, post-collectivisation period (1980-2003) as one that became increasingly inequitable, costly and ineffective. Since then, the introduction of the New Cooperative Medical Scheme (NCMS) and the beginning of the 'cover the countryside' campaign of public finance have resulted in far greater public funds being injected into the healthcare system. Despite this increase in funding, Manuel sees continuing problems during the next 20 years of health reform, unless the Chinese government can effectively address the flawed incentives facing individual health service providers and the lack of supervision, coordination and governance in the system. 


\section{References}

Brandt, L. and Rawski, T. G. 2008, 'China's great economic transformation', in L. Brandt and T. G. Rawski (eds), China's Great Economic Transformation, Cambridge University Press, Cambridge and New York, pp. 1-26.

Cai, F. and Du, Y. 2008, 'The political economy of emissions reduction in China: are incentives for low carbon growth compatible?', in L. Song and W. T. Woo (eds), China's Dilemma: Economic growth, the environment and climate change, ANU E Press and Brookings Institution Press, Canberra and Washington, DC, pp. 226-42.

Cai, F. and Wang, D. 2005, 'Demographic transition: implications for growth', in R. Garnaut and L. Song (eds), The China Boom and Its Discontents, Asia Pacific Press, Canberra, pp. 34-52.

Garnaut, R. 2008, Climate Change Review Report, Cambridge University Press, UK.

Garnaut, R. and Song, L. 2006, 'China's resources demand at the turning point', in R. Garnaut and L. Song (eds), The Turning Point in China's Economic Development, Asia Pacific Press, Canberra, pp. 276-93.

Lewis, W. A. 1955, The Theory of Economic Growth, Unwin University Books, London.

McKay, H. and Song, L. 2010, 'China as a global manufacturing powerhouse: strategic considerations and structural adjustment', China and World Economy, vol. 18, no. 1 (February), pp. 1-32.

Maddison, A. 2001, The World Economy: A millennial perspective, Organisation for Economic Cooperation and Development, Paris.

National Bureau of Statistics (NBS) 2007, China Statistical Yearbook 2007, China Statistics Press, Beijing.

Song, L., Wu, J. and Zhang, Y. (forthcoming), 'Urbanisation of migrant workers and expansion of domestic demand,' Social Sciences in China, vol. XXXI, no. 3 (August).

Stern, N. 2007, The Economics of Climate Change: The Stern review, Cambridge University Press, Cambridge and New York.

Thirlwall, A. P. 2006, Growth and Development with Special References to Developing Countries, Palgrave Macmillan, New York. 
Tyers, R., Golley, J. and Bain, I. 2009, 'Projected economic growth in the People's Republic of China and India: the role of demographic change', From Growth to Convergence: Asia's next two decades, Palgrave, London.

World Bank 2009, From Poor Areas to Poor People: China's evolving poverty reduction agenda, an assessment of poverty and inequality in China, March, East Asia and Pacific Region, The World Bank, Washington, DC. 
